\title{
Predictors of Hotel Guests' Water Conservation Intention in South Africa
}

\author{
Olawale Fatoki \\ https://orcid.org/0000-0003-1539-8333 \\ University of Limpopo \\ olawale.fatoki@ul.ac.za
}

Abstract

Purpose: South Africa is a water-scarce country and efforts to conserve water should focus on both demand and supply management. The study that directed this article, investigated the predictors of water conservation intention by hotel guests by extending the Theory of Planned Behaviour (TPB). Two constructs (environmental concern and water conservation activities in everyday life) were added to the TPB to develop a unique model of predictors of water conservation intention by hotel guests. The indirect effect of environmental concern was also examined.

Methodology: The study followed a quantitative research design. The crosssectional survey method was used for data collection from hotel guests and the Partial Least Square Structural Equation Modelling (PLS SEM) was used for data analysis.

Findings: The findings of the study indicated that the extended TPB model is useful in predicting the water conservation intention of hotel guests. In addition, attitude, perceived behavioural control and water conservation activities in everyday life mediate the relationship between environmental concern and intention.

Research implications: Theoretically, the study developed and tested a unique model of water conservation intention by extending the TPB. Managerial implications that focus on both management and guests are discussed.

Originality: The study developed and tested a unique model of predictors of water conservation intention by extending the TPB with two constructs and examining the mediation effect.

Keywords: water conservation; intention; Theory of Planned Behaviour; predictors; hotels; guests

\section{UNISA $\cong$}




\section{Introduction}

Tourism was one of the largest and fastest growing industries worldwide before the Covid-19 pandemic affected the movement of people locally and internationally in 2020 (Rogerson and Rogerson 2020). The tourism industry contributed $10.4 \%$ of the world's total gross domestic product (GDP) and accounted for one in 10 jobs globally in 2019 (World Travel and Tourism Council 2020). The tourism industry makes a significant contribution to the South Africa economy. The total contribution of the tourism industry to the GDP of South Africa was 8.2\% in 2018. In addition, tourism accounted for 9.2\% of the number of people employed in South Africa in 2018 (World Travel and Tourism Council 2019). Despite the major contribution of tourism to employment and economic growth, the industry also exerts significant pressure on the environment through the consumption of resources such as energy and water (Han and Yoon 2015). The majority of the negative environmental effects that conventional hotels have on the environment can be attributed to the excessive consumption of disposable products, energy and water (Saez-Fernandez, Jiménez-Hernández, and Ostos-Rey 2020; Untaru et al. 2016).

Fresh water is one of the important sources of water for tourism, as it is consumed for hygienic purposes such as the flushing of toilets and bathing. It is also used to wash bed and table linen, fill up swimming pools, cook food and irrigate gardens. Generally, the direct water use in hotels is between 84 and 2425 litres per guest per day (Gössling 2015; Gössling et al. 2012). While water demand is expected to increase, water supply will reduce in many countries because of the depletion of non-renewable fossil water resources and climate change (Mancosu et al. 2015). South Africa is a water-scarce country and is currently overexploiting its renewable water resources. The country needs to implement water conservation measures because of predictions of chronic water shortages by 2050 (Donnenfeld, Crookes, and Hedden 2018; Wade et al. 2014). Therefore, the efficient use of water is a key sustainability challenge for South Africa in general and the tourism industry in particular.

One of the major reasons for the high level of water consumption in the hospitality sector is the behavioural tendencies of guests. Many hotel guests have a "pleasure behaviour approach" to water use, especially when showering, and the hedonic nature of tourism is one of the barriers to sustainable consumption (Gabarda-Mallorquí et al. 2020; Untaru et al. 2016). Because of the increasing level of awareness of the importance of sustainable water management systems, many hotels have implemented strategies to reduce water consumption. However, such a strategy needs the support and participation of guests (Budovska, Delgado, and Øgaard 2020; Dimara, Manganari, and Skuras 2017). Water conservation can be defined as activities that lead to a reduction in the demand for water through improved efficiency of its use and a decrease in losses and waste (Kumari and Singh 2016). Dolnicar, Hurlimann, and Grun (2012) point out that, to ensure a country's long-term water supply, it is important to use both supplyside measures such as water augmentation through water recycling, and demand-side methods such as water conservation. Because of the growing number of people without 


\section{Fatoki}

access to water, the dwindling water supply worldwide and the need for sustainable tourism, it is necessary to understand the factors that influence consumers' water conservation behaviour (Budovska et al. 2020).

The three most commonly used theories in the domain of environmental psychology are the Norm-Activation-Theory (NAT) (Schwartz and Howard 1981), the Theory of Planned Behaviour (TPB) (Ajzen 1991), and the Value-Belief-Norm Theory (VBN) (Stern 2000). This is because the two major causes of pro-environmental behaviour are self-concept and self-interest. A positive self-concept is related to the moral norms of an individual, while self-interest maximises personal utility and explains why individuals are willing to change their behaviour because of some tangible benefits. Researchers that attribute the environmental behaviour of individuals as being motivated by self-concept, tend to use the NAT and the VBN. However, researchers who focus on self-interest motives and that the sustainable actions of an individual are a result of a rational evaluation of costs and benefits (effort, social approval, time), tend to rely on the TPB (Egea and Frutos 2013; Grazzini et al. 2018). The TPB is more adaptable to tourism and is more commonly used as the theoretical basis of empirical studies on eco-friendly intention and behaviour in the hospitality industry (Chaudhary et al. 2017; Wang et al. 2016). The TPB has three constructs (attitude, subjective norms and perceived behavioural control) and new variables can be added to the theory if they will lead to an improvement in the explanatory power of the model (Ajzen 1991).

Han et al. (2018) remark that the recent line of empirical research in tourism and hospitality is that the environmentally responsible decision-making process of individuals can be influenced by environmental concerns. However, the findings of empirical research are inconclusive about whether the effect of environmental concern on pro-environmental intention is direct or indirect. In addition, green habitual behaviour or environmentally friendly activities in everyday life have emerged as a significant predictor of pro-environmental intention (Han 2015).

Therefore, this study had three objectives: 1) to investigate how the three constructs of the TPB model will affect hotel guests' intention to conserve water; 2) to examine how the extended TPB model, that includes environmental concern and environmentally friendly activities in everyday life, have an effect on hotel guests' intention to conserve water; and 3) to investigate if the three TPB constructs and environmentally friendly activities in everyday life will mediate the relationship between environmental concern and intention to conserve water. The study that directed this article has theoretical, empirical and practical significance. Theoretically, the study tested the usefulness of the TPB and a unique extended model in explaining hotel guests' intention to conserve water. Empirically, the study extended water conservation research in the tourism industry, especially from the perspective of developing countries where studies have been relatively sparse. Practically, understanding the determinants of the water conservation intention of hotel guests is vital to sustainable tourism. 


\section{Fatoki}

In addition, South Africa is a water-scarce country and a signatory to the Paris Agreement on climate change. (United Nations Framework Convention on Climate Change 2015). Understanding the determinants of water conservation in the hospitality industry can help to reduce water demand and avoid the anticipated chronic water shortages in South Africa by 2050. Furthermore, reducing water use in the hospitality sector will diminish the exploitation of resources and contribute positively to climate change.

The paper is organised as follows. The literature review and development of hypotheses will be done in section two. The research methodology will be explained in section three. The results will be presented in section four. This will be followed by the discussion and conclusion in sections five and six respectively.

\section{Literature Review and Development of Hypotheses}

\section{Water Conservation in Hotels}

Kumari and Singh (2016) define water conservation as any beneficial reduction in water use, loss or waste. It is the process of saving water for future utilisation. The rationale for water conservation includes: 1) sustainability to ensure the availability of water for future generations; 2) energy conservation to reduce water pumping and delivery that normally consume a significant amount of energy; and 3) habitual conservation to reduce water use and preserve fresh water habitats. Water conservation is vital to the health of the ecosystem, biodiversity, life of human, aquatic and terrestrial organisms, and the livelihood of farmers, fishermen and individuals economically involved in tourism.

According to Han and Hyun (2018), water conservation is one of the most effective environmentally responsible practices in hotels and can bring benefits in the form of environmental and operational cost savings. Water conservation in hotels can be achieved through the replacement of existing appliances with water-efficient ones or a recycling system; and these are usually done by hotel management. Another effective way to achieve water conservation in hotels is to reduce guests' water consumption (Untaru et al. 2016). The use of water by guests occurs in the bathrooms of hotel rooms and involves activities such as showering, brushing of teeth and flushing of toilets. These activities are under the control of hotel guests. In order to achieve maximum water conservation, both hotel management and guests must be committed to water waste minimisation. Hotel management can help to conserve water by promoting best practices and installing the necessary equipment; and guests by behaving responsibly during their stay. Therefore, the active engagement of guests is essential for effective water conservation in hotels and it is important to understand the factors that drive guests' water conservation behaviour (Gabarda-Mallorquí, Fraguel, and Ribas 2018). 


\section{Theory of Planned Behaviour}

The Theory of Planned Behaviour (TPB) extends the Theory of Reasoned Action (TRA) (Ajzen 1991; Ajzen and Fishbein 1980). According to the TRA, intention forms the basis for actual behaviour. Intention is dependent on two factors, which are attitude and subjective norms (Ajzen and Fishbein 1980). The TPB also argues that intention determines the performance of a specific behaviour by an individual. However, intention is dependent on three factors, namely attitude, subjective norms and perceived behavioural control (Ajzen 1991). Attitude towards a behaviour is the extent to which an individual positively or negatively evaluates a behaviour. Subjective norms describe the possibility that an important individual, who is valued by an individual, will approve or disapprove of a behaviour. Perceived behavioural control describes the perceived difficulty or ease that an individual has in the performance of a behaviour (Ajzen 1991). The TPB has been used as the theoretical framework by studies on sustainable intention and behaviour (Bashir et al. 2019; Qi and Ploeger 2019). The conceptual framework of this study is based on the TPB because it provides a model that allows for the formation of hotel guests' intention to conserve water, that considers both volitional and nonvolitional factors.

\section{Attitude and Water Conservation Intention}

The positive attitude of an individual towards a particular behaviour reinforces his/her intention to perform the behaviour (Ajzen 1991). Sun and Willson (2008) point out that conceptually, there are two types of attitude. These are general attitude and specific attitude. A general attitude can be used to explain the general tendency to engage in certain behaviours, while a specific attitude is a relatively strong way to predict a single behaviour. However, a general attitude is likely to influence the formation of a specific attitude. The two types of attitude have been examined in research on intention formation, however, specific attitude is more useful to green behavioural intention. While general attitude represents judgements about environmental problems, specific attitude refers to the evaluation of a particular type of ecologically friendly product, service or behaviour (Nguyen et al. 2019; Zhang et al. 2019). According to Untaru et al. (2016), the findings of empirical studies that have considered general attitude towards conservation, rather than specific attitude, have been of limited use in the development of conservation interventions directed at changing behaviour.

The literature is not conclusive about the effect of attitude on intention. Han, Hsu, and Sheu (2010) tested the applicability of the TPB to the formation of intention to visit green hotels based on 428 respondents who were general lodging consumers in the United States of America (USA). The findings indicate a significant positive relationship between attitude and intention to stay in green hotels. Maichum, Parichatnon, and Peng (2016) examined the purchase intention of green products by consumers in Thailand, based on a study of 483 respondents. The findings reveal that attitude towards the purchasing of green products is positively associated with the intention to purchase green products. Zhang et al. (2019) in a Chinese study of 223 


\section{Fatoki}

respondents, found that attitude towards green products had a significant positive relationship with the purchase intention of energy efficient household appliances. In the context of water conservation by hotel guests, Untaru et al. (2016) tested the applicability of the TRA to predict hotel guests' intention to conserve water in Romania. Based on a sample of 354 respondents, the findings indicate that attitude towards water conservation behaviour is positively associated with guests' intention to conserve water. Peren and Yang (2015) used the TPB to investigate the intention of consumers to engage in water conservation at home, based on a survey of 174 individuals in Greece. The findings show that the effect of attitude is insignificant. Based on theoretical persuasion and prior empirical findings, it is hypothesised that:

Hypothesis 1: Attitude towards water conservation is positively associated with hotel guests' intention to conserve water.

\section{Subjective Norms and Water Conservation Intention}

Social trust, knowledge of what is done by other people and social integration can play a significant part in eco-friendly behaviour such as energy conservation (Sweeney, Soutar, and Mazzarol 2014). The findings of empirical studies on the relationship between subjective norms and intention in the context of eco-friendly goods and services are inconclusive. Han et al. (2010) found a significant positive relationship between subjective norms and intention to stay in green hotels. The findings of Maichum et al. (2016) indicate that subjective norms are positively associated with the intention to purchase green products. Untaru et al. (2016) found a significant positive relationship between subjective norms and hotel guests' intention to conserve water. Zhang et al. (2019) found that the relationship between subjective norms and purchase intention of energy efficient household appliances was insignificant. Han and Hyun (2018), in a study on the factors influencing water conservation of hotel consumers in the USA, found that both descriptive and injunctive social norms had positive but insignificant relationships with water conservation intention. The opinion of an important person or group on conservation may influence the intention of a guest to conserve water. It is hypothesised that:

Hypothesis 2: Subjective norms have a positive effect on guests' intention to conserve water.

\section{Perceived Behavioural Control and Water Conservation Intention}

Zhang et al. (2019) remark that perceived behaviour control is reflected by aspects such as perceived inconvenience, cost, time and resources. The findings of empirical studies on the relationship between perceived behavioural control and intention to purchase green products are inconclusive. Maichum et al. (2016) found a significant positive relationship between perceived behavioural control and purchase intention for green products. Nguyen et al. (2019) tested the applicability of the TPB in explaining consumers' green product purchase intentions in Vietnam. The findings indicate a 


\section{Fatoki}

significant positive relationship between perceived behavioural control and intention. Wang et al. (2016) found a significant positive relationship between perceived behavioural control and intention to purchase organic clothing and energy efficient household appliances in China. Arvola et al. (2008) found an insignificant effect of perceived behavioural control on intentions to purchase organic pizza and apples. The perceived ease of water conservation by guests will positively affect the intention to conserve water. It is hypothesised that:

Hypothesis 3: Perceived behaviours control is positively associated with guests' water conservation intention.

Extension of the TPB in the Context of Eco-friendly Behaviour

Table 1 depicts some studies that have extended the TPB in the context of eco-friendly consumption and behaviour. This study used water conservation activities in everyday life and environmental concern to extend the TPB. 
Fatoki

\begin{tabular}{|c|c|c|c|c|}
\hline $\begin{array}{l}\text { Author and } \\
\text { country }\end{array}$ & Purpose & $\begin{array}{l}\text { Variables used } \\
\text { to extend TPB }\end{array}$ & Methodology & Findings \\
\hline $\begin{array}{l}\text { Lam (2006) } \\
\text { Taiwan }\end{array}$ & $\begin{array}{l}\text { The study examined } \\
\text { predictors of water } \\
\text { conservation } \\
\text { intention using the } \\
\text { TPB. }\end{array}$ & $\begin{array}{l}\text { Perceived moral } \\
\text { obligation and } \\
\text { perceived water } \\
\text { right }\end{array}$ & $\begin{array}{l}\text { Survey of } 244 \\
\text { government } \\
\text { employees }\end{array}$ & $\begin{array}{l}\text { Perceived water } \\
\text { rights and TPB } \\
\text { variables affect } \\
\text { the intention to } \\
\text { install water } \\
\text { efficient } \\
\text { appliances. }\end{array}$ \\
\hline $\begin{array}{l}\text { Chen and } \\
\text { Tung (2014) } \\
\text { Taiwan }\end{array}$ & $\begin{array}{l}\text { The TPB extended } \\
\text { to predict intention } \\
\text { to visit green hotels }\end{array}$ & $\begin{array}{l}\text { Environmental } \\
\text { concern and } \\
\text { perceived moral } \\
\text { obligation }\end{array}$ & $\begin{array}{l}\text { Data collected from } \\
559 \text { respondents. } \\
\text { Structural equation } \\
\text { modelling used for } \\
\text { data analysis } \\
\end{array}$ & $\begin{array}{l}\text { Environmental } \\
\text { concern positively } \\
\text { affects TPB } \\
\text { variables. }\end{array}$ \\
\hline $\begin{array}{l}\text { Perren and } \\
\text { Yang } \\
(2015) \\
\text { Greece }\end{array}$ & $\begin{array}{l}\text { Psychosocial and } \\
\text { behavioural factors } \\
\text { affect water saving } \\
\text { intention at home }\end{array}$ & $\begin{array}{l}\text { Information } \\
\text { exposure and } \\
\text { current } \\
\text { engagement in } \\
\text { water saving } \\
\text { actions }\end{array}$ & $\begin{array}{l}\text { Hierarchical } \\
\text { regression analysis }\end{array}$ & $\begin{array}{l}\text { Intention to save } \\
\text { water is } \\
\text { determined by } \\
\text { engagement in } \\
\text { water-saving } \\
\text { behaviour }\end{array}$ \\
\hline $\begin{array}{l}\text { Chaudhary } \\
\text { et al. (2017) } \\
\text { USA }\end{array}$ & $\begin{array}{l}\text { Extension of the } \\
\text { TPB for water } \\
\text { conservation among } \\
\text { extension clients }\end{array}$ & $\begin{array}{l}\text { Personal norms, } \\
\text { demographic } \\
\text { factors, and past } \\
\text { behaviours }\end{array}$ & $\begin{array}{l}\text { Survey used for data } \\
\text { collection. } \\
\text { hierarchical linear } \\
\text { regression models } \\
\text { used for data } \\
\text { analysis }\end{array}$ & $\begin{array}{l}\text { Extended TPB } \\
\text { predicts water } \\
\text { conservation. }\end{array}$ \\
\hline $\begin{array}{l}\text { Wang et al. } \\
\text { (2016) } \\
\text { China }\end{array}$ & $\begin{array}{l}\text { Extended TPB to } \\
\text { predict intention to } \\
\text { visit green hotels in } \\
\text { China }\end{array}$ & $\begin{array}{l}\text { Perceived } \\
\text { consumer } \\
\text { effectiveness and } \\
\text { environmental } \\
\text { concern. }\end{array}$ & $\begin{array}{l}\text { Data collected from } \\
324 \text { respondents in a } \\
\text { survey. Structural } \\
\text { Equation Modelling } \\
\text { used for data } \\
\text { analysis. }\end{array}$ & $\begin{array}{l}\text { Perceived } \\
\text { consumer } \\
\text { effectiveness and } \\
\text { environmental } \\
\text { concern positively } \\
\text { affect the } \\
\text { intention of } \\
\text { consumers to visit } \\
\text { green hotels }\end{array}$ \\
\hline $\begin{array}{l}\text { Bashir et al. } \\
\text { (2019) } \\
\text { Malaysia }\end{array}$ & $\begin{array}{l}\text { Extended TPB to } \\
\text { predict the } \\
\text { behaviour of } \\
\text { consumers in green } \\
\text { hotels }\end{array}$ & $\begin{array}{l}\text { Personal norms, } \\
\text { intention towards } \\
\text { green hotels, } \\
\text { environmental } \\
\text { consciousness, } \\
\text { and green } \\
\text { consumer } \\
\text { behaviour }\end{array}$ & $\begin{array}{l}\text { Data collected from } \\
394 \text { lodging } \\
\text { consumers. } \\
\text { Structural equation } \\
\text { modelling used for } \\
\text { data analysis }\end{array}$ & $\begin{array}{l}\text { Personal norms } \\
\text { and behavioural } \\
\text { intention } \\
\text { positively affect } \\
\text { green behaviour. }\end{array}$ \\
\hline $\begin{array}{l}\text { Warner and } \\
\text { Diaz (2020) } \\
\text { USA }\end{array}$ & $\begin{array}{l}\text { Extended TPB used } \\
\text { to predict water } \\
\text { conservation } \\
\text { programme }\end{array}$ & $\begin{array}{l}\text { Connectedness to } \\
\text { water }\end{array}$ & $\begin{array}{l}\text { Data collected from } \\
3596 \text { residents. } \\
\text { Multiple regression } \\
\text { used for data } \\
\text { analysis. }\end{array}$ & $\begin{array}{l}\text { Connectedness to } \\
\text { water increased } \\
\text { the predictive } \\
\text { power of the TPB }\end{array}$ \\
\hline $\begin{array}{l}\text { Arya and } \\
\text { Chaturvedi } \\
(2020) \\
\text { India }\end{array}$ & $\begin{array}{l}\text { Extending the TPB } \\
\text { to explain energy } \\
\text { saving behaviour }\end{array}$ & $\begin{array}{l}\text { Consideration for } \\
\text { future } \\
\text { consequences }\end{array}$ & $\begin{array}{l}\text { Data collected } \\
\text { online from college } \\
\text { students. Regression } \\
\text { analysis used for } \\
\text { data analysis. }\end{array}$ & $\begin{array}{l}\text { Extended TPB } \\
\text { predicts energy } \\
\text { saving behaviour }\end{array}$ \\
\hline
\end{tabular}




\section{Fatoki}

\section{Water Conservation Activities in Everyday Life and Water Conservation Intention}

Water conservation activities or behaviour includes understanding the reason for saving water, reduction in losses and waste and having water-saving behaviour every day. These activities that are done by individuals at home every day and may become habitual, include turning the water off during brushing of teeth and turning the shower off when soaping (Sarabia-Sánchez, Rodriquez-Sánchez, and Hyder 2014). These ecofriendly habitual behaviours are a significant predictor of pro-environmental intention/behaviour (Han et al. 2018. The findings of the study by Han et al. (2010) show that environmentally friendly activities of hotel guests at home are positively related to their pro-environmental purchasing decision. In addition, hotel guests' high level of environmentalism in everyday life improves the intention to reuse towels (Dimara et al. 2017). Untaru et al. (2016), using the extended TRA, found that water conservation activities in everyday life have a significant positive relationship with intention to conserve water in a lodging context. Han and Hyun (2018) found a significant positive relationship between water conservation in everyday life and intention to conserve water in the hospitality industry. Consequently, it is hypothesised that:

Hypothesis 4: There is a significant positive relationship between water conservation activities in everyday life and hotel guests' water conservation intention.

\section{Environmental Concern and Water Conservation Intention}

Chen and Tung (2014) describe environmental concern as a general attitude toward environmental protection, and an important factor in how individuals change their behaviour to become more ecologically friendly. Many empirical studies have directly linked environmental concern to green purchase intention and behaviour. Wang et al. (2016) used the extended version of the TPB to examine consumers' intention to adopt hybrid vehicles in China. The study found that environmental concern was positively associated with the intention to purchase hybrid vehicles. Li et al. (2019) found that environmental concern had a direct significant positive relationship with intention to purchase energy efficient appliances in China. Bamberg (2013), however, points out that a meta-analysis of studies revealed that the direct relationship between environmental concern and specific environmentally related behaviour was weak, with the majority of empirical findings showing low to moderate relationship. This can be attributed to the incorrect assumption that general attitudes, like environmental concern, can directly predict specific behaviours (Bamberg 2013). Therefore, future research should not view environmental concern as a direct, but rather an indirect predictor of specific behaviour. Ajzen and Fishbein (1980) suggest that general attitude, like environmental concern, does not relate to a specific behaviour directly, but indirectly. In addition, an individual's attitude, subjective norm, and perceived behavioural control are affected by his/her general attitude through situation-specific behavioural, normative, and control beliefs. Chen and Tung (2014), in a study on consumer intention 


\section{Fatoki}

to visit green hotels, found that attitude, subjective norms, perceived behavioural control and perceived moral obligation were affected by environmental concern. Untaru et al. (2016) tested the effect of environmental concern on the two TRA constructs and water conservation activities in everyday life. The results indicate that environmental concern significantly affects attitude and water conservation activities in everyday life, but has an insignificant effect on subjective norms. Zhang et al. (2019), in a study that extended the TPB to explain the effects of cognitive factors across different types of green products in China, found a significant positive relationship between environmental concern and the three TPB constructs. Maichum et al. (2016) found that environmental concern had a significant direct positive effect on the intention to purchase green products. In addition, environmental concern positively affects attitude towards purchasing green products and perceived behavioural control, but has an insignificant effect on subjective norms. Chen and Tung (2014) found that consumers' environmental concern positively influenced attitude toward visiting green hotels, subjective norms, perceived behavioural control, and perceived moral obligation. Untaru et al. (2016), in a study that used the TRA, examined the mediating effect of attitude, subjective norms and water conservation activities in everyday life in the relationship between environmental concern and water conservation intention. The findings indicate that among the three mediator variables, only attitude mediated the effect of environmental concern on water conservation intentions.

This current study added environmental concern to the TPB and considered both the direct and indirect effects. It is hypothesised that:

Hypothesis 5: Environmental concern is positively related to hotel guests' intention to conserve water.

Hypotheses 6-9: Environmental concern is positively related to attitude, subjective norms, perceived behavioural control and water conservation activities in everyday life. 


\section{Fatoki}

Hypotheses 10-13: Attitude, subjective norms, perceived behavioural control and water conservation activities in everyday life mediate the relationship between environmental concern and water conservation intention.

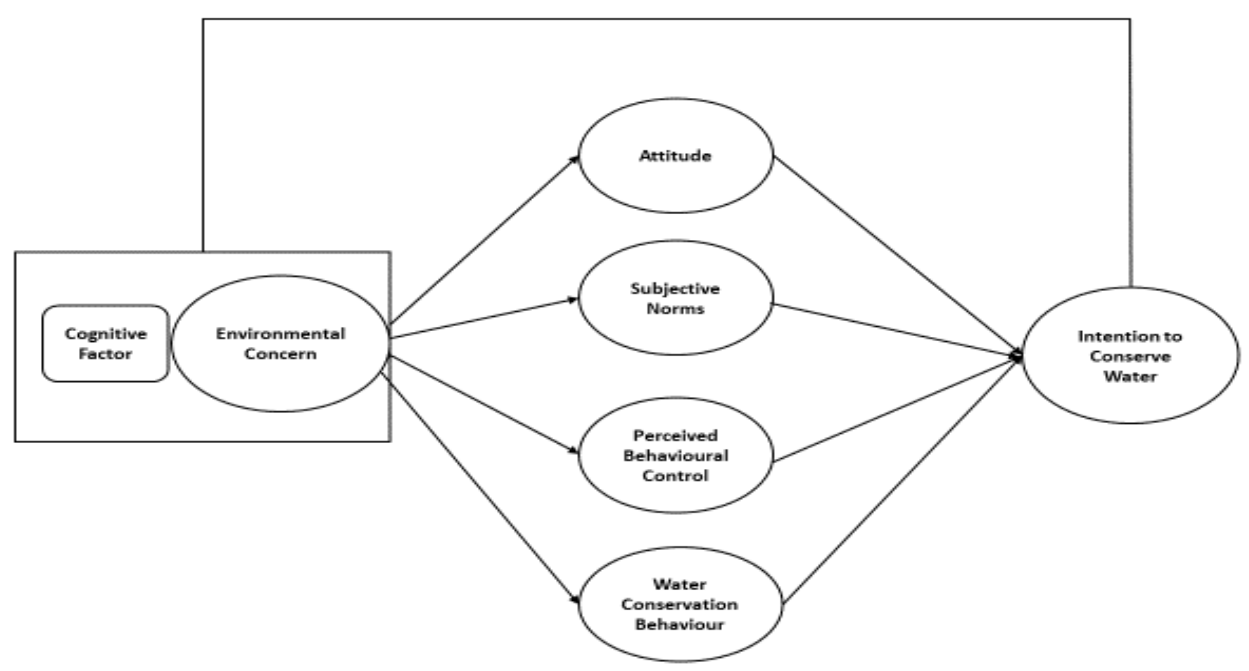

Figure 1: The conceptual framework

Source: Author's conceptualisation

\section{Research Methodology}

The study adopted a quantitative research approach. The cross-sectional survey method was used to collect data from the participants. The participants were guests that stayed in selected hotels, lodges and guest houses in Pretoria, Johannesburg and Polokwane. Pretoria and Johannesburg are located in the Gauteng province, while Polokwane is located in the Limpopo province. Pretoria is the administrative capital of South Africa and Johannesburg, the major economic hub, and many hospitality firms are located in the two cities. Polokwane is the capital of the Limpopo Province, with many hotels and visitors. The researcher conveniently sampled the participating hospitality firms from the websites of the Tourism Grading Council of South Africa (TGCSA) and Trivago. TGCSA helps guests to compare the standards of different hotels while Trivago assists guests to search for available hotels.

A pilot study was conducted with 30 hotel guests in Polokwane before the actual survey. The participants in the pilot study did not participate in the main survey. The questionnaire used for the survey was examined by two academics in the area of sustainability to ensure face and content validity. Before the distribution of questionnaires, the researcher contacted the managers/owners of 70 accommodation 


\section{Fatoki}

establishments to solicit their participation. This was done through telephone calls and e-mails and 20 hotels agreed to participate in the survey. Fifty questionnaires were distributed in each participating hotel and to respect the privacy of hotel visitors, only willing hotels and visitors were selected for participation in the survey. In addition, the objectives of the study and its benefits to the hospitality industry were described in a covering letter. The participants in the survey were recruited at the hotels and additional questionnaires were left in the reception halls and dining rooms. These questionnaires were collected after completion with the assistance of hotel employees. The researcher ensured the confidentiality and anonymity of the hotels and guests that participated in the survey. Therefore, the names of the hotels and guests were not asked for. Appendix one depicts the full questionnaire, and ethical clearance was obtained from the author's university before data collection. The Partial Least Square Structural Equation Modelling (PLS SEM) was used for data analysis.

\section{Results}

\section{Response Rate and Biographical Details}

One-thousand questionnaires were distributed to respondents and 416 questionnaires were returned and found usable. Eighteen questionnaires were not usable because the respondents failed to complete significant questionnaire items. The "rule of 10 " was used to determine the appropriate minimum sample size to test the model. According to Hair et al. (2011), when using PLS SEM to test a model, the minimum sample size should be 10 times the highest number of structural paths directed at the latent construct at a time. In this study, there were 23 question items (appendix one) and so a minimum of 230 respondents would be needed. However, 416 useable questionnaires were obtained. There were 231 male and 185 female respondents. The age distribution was as follows: 18-20 years, 17 respondents; 21-30, 62 respondents; 31-40, 145 respondents; 41-50, 136 respondents; 51-60, above 60. Altogether 348 respondents had post matric qualifications (diplomas and degrees) and 86 respondents had a matric qualification.

\section{Descriptive Statistics}

Table 1 depicts the results of the descriptive statistics. The results indicate that the standard deviations of all constructs are below one and within acceptable range The skewness and kurtosis values for all constructs range between +2 and -2 . 
Table 1: Descriptive statistics

\begin{tabular}{|c|c|c|c|c|}
\hline Construct & Mean & SD & Skewness & Kurtosis \\
\hline Attitude & 4.05 & 0.86 & 0.77 & 0.11 \\
\hline $\begin{array}{l}\text { Subjective } \\
\text { norms }\end{array}$ & 3.12 & 0.91 & -0.72 & 1.08 \\
\hline $\begin{array}{l}\text { Perceived } \\
\text { behaviour } \\
\text { control }\end{array}$ & 3.97 & 0.77 & 0.64 & 0.53 \\
\hline $\begin{array}{l}\text { Water } \\
\text { conservation } \\
\text { activities }\end{array}$ & 3.66 & 0.82 & 0.73 & 0.72 \\
\hline $\begin{array}{l}\text { Environmental } \\
\text { concern }\end{array}$ & 4.02 & 0.89 & -0.81 & 0.25 \\
\hline Intention & 3.55 & 0.79 & 0.69 & 0.69 \\
\hline
\end{tabular}

\section{Structural equation modelling}

\section{The Evaluation of the Measurement Model}

The criteria highlighted by Hair et al. (2019) were used to evaluate the measurement model. These are factor loadings $(>0.708)$, composite reliability (between 0.790 and $0.900)$, Cronbach's alpha $(>0.700)$ and the Average Variance Extracted (AVE) (>0.500). In addition, the square roots of the AVEs should be greater than the correlations amongst variables. Tables 2 and 3 show that all the criteria were met. 
Fatoki

Table 2: The measurement model

\begin{tabular}{|c|c|c|c|c|c|}
\hline Construct & $\begin{array}{l}\text { Measurement } \\
\text { items }\end{array}$ & $\begin{array}{l}\text { Item } \\
\text { loading }\end{array}$ & $\begin{array}{l}\text { Cronbach's } \\
\text { alpha }\end{array}$ & $\begin{array}{l}\text { Composite } \\
\text { reliability }\end{array}$ & AVE \\
\hline \multirow[t]{4}{*}{ Attitudes (ATT) } & ATT1 & 0.829 & 0.805 & 0.858 & 0.600 \\
\hline & ATT2 & 0.724 & & & \\
\hline & ATT3 & 0.817 & & & \\
\hline & ATT4 & 0.731 & & & \\
\hline \multirow{3}{*}{$\begin{array}{l}\text { Subjective norms } \\
\text { (SN) }\end{array}$} & SN1 & 0.723 & 0.746 & 0.802 & 0.575 \\
\hline & $\mathrm{SN} 2$ & 0.749 & & & \\
\hline & SN3 & 0.802 & & & \\
\hline \multirow{3}{*}{$\begin{array}{l}\text { Perceived } \\
\text { behavioural } \\
\text { control } \\
\end{array}$} & $\mathrm{PBC} 1$ & 0.890 & 0.811 & 0.850 & 0.655 \\
\hline & PBC2 & 0.801 & & & \\
\hline & PBC3 & 0.730 & & & \\
\hline \multirow{7}{*}{$\begin{array}{l}\text { Environmental } \\
\text { concern (EC) }\end{array}$} & $\mathrm{EC} 1$ & 0.801 & 0.726 & 0.900 & 0.563 \\
\hline & EC2 & 0.728 & & & \\
\hline & EC3 & 0.761 & & & \\
\hline & EC4 & 0.779 & & & \\
\hline & EC5 & 0.722 & & & \\
\hline & EC6 & 0.731 & & & \\
\hline & EC7 & 0.727 & & & \\
\hline \multirow{3}{*}{$\begin{array}{l}\text { Water } \\
\text { conservation } \\
\text { activities (WCA) }\end{array}$} & WCA1 & 0.806 & 0.800 & 0.825 & 0.610 \\
\hline & WCA2 & 0.801 & & & \\
\hline & WCA3 & 0.736 & & & \\
\hline \multirow[t]{3}{*}{ Intention (INT) } & INT1 & 0.844 & 0.733 & 0.836 & 0.631 \\
\hline & INT2 & 0.803 & & & \\
\hline & INT3 & 0.732 & & & \\
\hline
\end{tabular}

Table 3: Discriminant validity

\begin{tabular}{|l|r|r|r|r|r|r|}
\hline Construct & \multicolumn{1}{|l|}{ INT } & \multicolumn{1}{l|}{ ATT } & \multicolumn{1}{l|}{ SN } & \multicolumn{1}{l|}{ PBC } & \multicolumn{1}{l|}{ EC } & \multicolumn{1}{l|}{ WCA } \\
\hline INT & $\mathbf{0 . 7 9 4}$ & & & & & \\
\hline ATT & 0.484 & $\mathbf{0 . 7 5 8}$ & & & & \\
\hline SN & 0.308 & 0.401 & $\mathbf{0 . 7 5 8}$ & & & \\
\hline PBC & 0.529 & 0.613 & 0.524 & $\mathbf{0 . 8 0 9}$ & & \\
\hline EC & 0.530 & 0.622 & 0.526 & 0.518 & $\mathbf{0 . 7 5 0}$ & \\
\hline WCA & 0.526 & 0.613 & 0.403 & 0.529 & 0.402 & $\mathbf{0 . 7 8 1}$ \\
\hline
\end{tabular}

Note: Diagonal values depict the square root of AVEs for the constructs. 


\section{Structural Model Assessment}

In order to assess the structural model, the common method bias (CMB), the coefficient of determination $\left(\mathrm{R}^{2}\right)$, the predictive relevance of the model $\left(\mathrm{Q}^{2}\right)$, the goodness of fit (GOF), the effect size, the standardised root mean square residual (SRMR) and the evaluation of the path coefficients need to be examined (Hair et al. 2019). The values of the variance inflation factor (VIF) range from 1.209 to 2.620. This suggests that the model is free of CMB as the VIF values are below 3.3. The $\mathrm{R}^{2}$ of the original TPB model accounted for $39.3 \%$ of the variance. The extended model explained $51.9 \%$ of the variance. When using PLS SEM, $\mathrm{R}^{2}$ values of $0.26,0.50$ and 0.75 are considered weak, moderate and substantial respectively. The GOF of 0.561 shows that the empirical data were sufficiently captured by the model and the $\mathrm{Q}^{2}$ of 0.61 suggests a highly predictive model. The effect size, $f^{2}$, ranged from 0.115 to 0.142 indicating that the effect sizes of different endogenous constructs on the exogenous construct were satisfactory. The standardised root mean square residual (SRMR) of 0.02 suggests a good model fit. Table 4 depicts the results of the path coefficients.

Table 4: Path coefficient and t-statistics

\begin{tabular}{|l|l|l|l|}
\hline Hypothesised path & Standardised Beta & T-statistics & Decision \\
\hline H1 ATT $\rightarrow$ INT & 0.209 & $7.144^{*}$ & Supported \\
\hline H2 SN $\rightarrow$ INT & 0.142 & $2.409^{* *}$ & Supported \\
\hline H3 PBC $\rightarrow$ INT & 0.191 & $4.085^{* *}$ & Supported \\
\hline H4 WCA $\rightarrow$ INT & 0.186 & $3.729^{*}$ & Supported \\
\hline H5 EC $\rightarrow$ INT & 0.208 & $3.409^{* *}$ & Supported \\
\hline H6 EC-ATT & 0.185 & $2,592^{*}$ & Supported \\
\hline H7 EC-SN & 0.042 & 0.083 & Not supported \\
\hline H8 EC-PBC & 0.105 & $3.007^{* *}$ & Supported \\
\hline H9 EC-WCA & 0.201 & $3.283^{*}$ & Supported \\
\hline
\end{tabular}

Note: $* \mathrm{P}<0.01 ; * *<0.05$

Table 5: Mediation results

\begin{tabular}{|c|c|c|c|c|c|}
\hline Mediation path & $\begin{array}{l}\text { Indirect } \\
\text { effect }\end{array}$ & $\begin{array}{l}\text { Total effect } \\
\text { and T- } \\
\text { statistics }\end{array}$ & $\begin{array}{l}\text { Confidence } \\
\text { interval bias } \\
\text { (corrected) }\end{array}$ & Decision & VAF \\
\hline & & & $\begin{array}{l}\text { LL } \\
\text { UL }\end{array}$ & & \\
\hline $\begin{array}{l}\mathrm{H} 10 \\
\mathrm{EC} \rightarrow \mathrm{ATT} \rightarrow \mathrm{INT}\end{array}$ & $0.109 * *$ & $\begin{array}{l}0.135^{*} \\
(3.608)\end{array}$ & $\begin{array}{l}0.444 \\
0.208 \\
\end{array}$ & $\begin{array}{l}\text { Accepted } \\
\text { (full mediation) }\end{array}$ & $80.74 \%$ \\
\hline $\mathrm{H} 11 \mathrm{EC} \rightarrow \mathrm{SN} \rightarrow \mathrm{INT}$ & 0.064 & $\begin{array}{l}0.392 \\
(1.129)\end{array}$ & $\begin{array}{l}0.064 \\
0.308\end{array}$ & $\begin{array}{l}\text { Rejected } \\
\text { No mediation) }\end{array}$ & $16.32 \%$ \\
\hline $\begin{array}{l}\mathrm{H} 12 \\
\mathrm{EC} \rightarrow \mathrm{PBC} \rightarrow \mathrm{INT}\end{array}$ & $0.112 * *$ & $\begin{array}{l}0.268 * * \\
(1.110)\end{array}$ & $\begin{array}{l}0.072 \\
0.299\end{array}$ & $\begin{array}{l}\text { Accepted } \\
\text { (partial } \\
\text { mediation) }\end{array}$ & $41.79 \%$ \\
\hline $\begin{array}{l}\mathrm{H} 13 \\
\mathrm{EC} \rightarrow \mathrm{WCA} \rightarrow \mathrm{INT}\end{array}$ & $0.117 *$ & $\begin{array}{l}0.518^{*} \\
(1.108)\end{array}$ & $\begin{array}{l}0.061 \\
0.179\end{array}$ & $\begin{array}{l}\text { Accepted } \\
\text { (partial } \\
\text { mediation) }\end{array}$ & $22.58 \%$ \\
\hline
\end{tabular}




\section{Fatoki}

Note: $* \mathrm{P}<0.01 ; * *<0.05$

The results as depicted in table 4, show that three TPB constructs have direct and significant positive relationships with water conservation intention. Therefore, hypotheses 1, 2 and 3 are accepted. In addition, the constructs used to extend the TPB (environment concern and water conservation activities) have significant positive relationships with water conservation intention. Hypotheses 4 and 5 are supported. The results also indicate that environmental concern has significant positive relationships with attitude, perceived behavioural control and water conservation activities. Hypotheses 6, 8 and 9 are supported. The effect of environmental concern on subjective norms is insignificant and hypothesis 7 is not supported. Table 5 depicts the results of mediation. The existence of full or partial mediation can be determined by the Variance Accounted For (VAR). If the VAR is less than $20 \%$, mediation is close to zero, for a VAR value between $20 \%$ and $80 \%$ (partial mediation) and above $80 \%$ (full mediation) (Hair et al. 2019; Nitzl, Roldan, and Cepeda-Carrion 2016). The indirect paths between EC and ATT, PBC and WCA and intention are positive and significant. Thus, a complementary partial mediation is confirmed. The indirect path of EC and ATT and INT shows full complementary mediation. The indirect paths of EC and PBC, WCA and intention show partial complementary mediation. Thus, Hypotheses 10, 12 and 13 are supported. The indirect path between EC, SN and INT is insignificant. Hypothesis 11 is not supported.

\section{Discussion}

The study which directed this article examined the predictors of hotel guests' intention to conserve water. This study had three objectives: 1) to investigate how the three constructs of the TPB model will affect hotel guests' intention to conserve water; 2) to examine the effect of the extended TPB model that includes environmental concern and environmentally friendly behaviours in everyday life on hotel guests' intention to conserve water; and 3 ) to investigate if the three TPB constructs and environmentally friendly behaviours in everyday life will mediate the relationship between environmental concern and intention to conserve water.

The findings of the study support the applicability of the TPB model in predicting hotel guests' intention to conserve water. The three TPB constructs have significant positive relationships with intention to conserve water. The results indicate that individuals with a positive attitude towards water conservation are likely to conserve water when staying in hotels. In addition, the opinions of people that are important to the guest can influence water conservation. Also, the availability of knowledge about water conservation can positively affect water conservation behaviour. The findings of this study are supported by the results of prior empirical studies. Untaru et al. (2016) used the TRA to investigate the intention of guests to conserve water when staying in a lodging establishment. The results indicate that attitude towards water conservation behaviour and subjective norms are positively associated with guests' intention to conserve water. Maichum et al. (2016) 


\section{Fatoki}

found that attitude, subjective norms and perceived behavioural control were positively associated with the purchase intention of green products.

Two constructs (environmental concern and water conservation activities in everyday life) were used to extend the TPB. The results indicate significant positive relationships between the two constructs and intention to conserve water. The results are consistent with the findings of previous empirical studies. Untaru et al. (2016) found that environmental concern and water conservation activities in everyday life had significant positive relationships with intention to conserve water in a lodging context. The findings of the study by Han and Hyun (2018) show significant positive relationships between environmental concern and water conservation activities in everyday life, and intention to conserve water in the hospitality industry. The study also examined the indirect effect of EC in line with the suggestions of Bamberg (2013). The results indicate that attitude fully mediates the relationship between environmental concern and intention, while the effects of perceived behavioural control and water conservation activities in everyday life show partial mediation. The results are consistent with the findings of similar empirical studies. Maichum et al. (2016) found that that environmental concern positively affected attitude towards purchasing green products and perceived behavioural control, but had an insignificant effect on subjective norms. Chen and Tung (2014) found that consumers' environmental concern positively affected attitude toward visiting green hotels, subjective norms, perceived behavioural control and perceived moral obligation. Untaru et al. (2016) found that attitude mediated the effect of environmental concern on water conservation intentions.

\section{Conclusion}

The study examined, by applying the TPB, the predictors of hotel guests' intention to conserve water. The study also investigated the effect of the extended TPB model that included environmental concern and water conservation activities in everyday life. The findings indicate that the TPB and the extended model are applicable in predicting water conservation intention. Theoretically, the study developed and tested a unique model for the predictors of water conservation intention by hotel guests. Empirically, the study adds to the literature on factors that can help to improve water conservation, especially in South Africa.

The study has some managerial implications. To improve attitude towards water conservation, perceived behavioural control and environmental concern of guests, hotel management should develop water conservation messages. For instance, putting cards and notices that contain water conservation information in the rooms, bathrooms and strategic locations and on their websites. This kind of messaging will show that water conservation is good behaviour that can help to prevent the exhaustion of resources and save the planet. This will help to create awareness about environmental protection and shift the behaviour of guests towards sustainable consumption. To improve subjective norms, previous guests that have stayed in hotels should be used in marketing campaigns on various media platforms to share the benefits of water conservation and encourage 


\section{Fatoki}

potential visitors to conserve water. To improve water conservation activities at home, which can affect the water conservation behaviour of hotel guests, governments, nongovernmental organisations and media should continue to emphasise the need to conserve water at home and work in order to protect the environment for today and future generations.

The study has the following limitations and areas for further study. The study focused on the predictors of intention and not actual behaviour. Intention does not always predict behaviour and other studies can investigate the predictors of water conservation behaviour of hotel guests. The explanatory power of the TPB, in the context of water conservation intention, can also be further improved through the inclusion of other personal variables such as anticipated guilt, pride and moral norms. The moderating effects of socio-demographic variables (level of income, age, gender, level of education) and the influence of stay characteristics variables (length of stay and loyalty) can also be examined.

\section{References}

Ajzen, I. 1991. "The Theory of Planned Behaviour." Organizational Behaviour and Human Decision Processes, no. 50: 179-211. https://doi.org/10.1016/0749-5978(91)90020-T.

Ajzen I., and M. Fishbein. 1980. Understanding Attitudes and Predicting Social Behavior. Englewood Cliffs, NJ: Prentice-Hall.

Arvola, A., M. Vassallo, M. Dean, and P. Lampila. 2008. "Predicting Intentions to Purchase Organic Food: The Role of Affective and Moral Attitudes in the Theory of Planned Behaviour." Appetite 50 (2-3): 443-54. https://doi.org/10.1016/j.appet.2007.09.010.

Arya, B., and S. Chaturvedi. 2020. "Extending the Theory of Planned Behaviour to Explain Energy Saving Behaviour.” Environmental and Climate Technologies 24 (1): 516-528. https://doi.org/10.2478/rtuect-2020-0032.

Bamberg, S. 2013. "Changing Environmentally Harmful Behaviours: A Stage Model of Selfregulated Behavioral Change.” Journal of Environmental Psychology, no. 34: 151-159. https://doi.org/10.1016/j.jenvp.2013.01.002.

Bashir, S., M. Khwaja, J. Ali, and H. Toheed. 2019. "Extension of Planned Behavioral Theory to Consumer Behaviors in Green Hotel.” Heliyon 5 (12): e02974. https://doi.org/10.1016/j.heliyon.2019.e02974.

Budovska, V., A. Delgado, and T. Øgaard. 2020. "Pro-environmental Behaviour of Hotel Guests: Application of the Theory of Planned Behaviour and Social Norms to Towel Reuse." Tourism and Hospitality Research 20 (1): 105-116. https://doi.org/10.1177/1467358419831431. 


\section{Fatoki}

Chaudhary, A. K., L. A, Warner, A. Lamm, and G. Israel. 2017. "Using the Theory of Planned Behavior to Encourage Water Conservation among Extension Clients." Journal of Agricultural Education 58 (3): 185-202. https://doi.org/10.5032/jae.2017.03185.

Chen, M., and P. Tung. 2014. "Developing an Extended Theory of Planned Behaviour Model to Predict Consumers' Intention to Visit Green Hotels International." Journal of Hospitality. Management, no. 36: 221-230. https://doi.org/10.1016/j.ijhm.2013.09.006.

Dimara, E., E. Manganari, and D. Skuras. 2017. "Don’t Change my Towels please: Factors Influencing Participation in Towel Reuse Programs." Tourism Management, no. 59: 425437. https://doi.org/10.1016/j.tourman.2016.09.003.

Dolnicar, S., A. Hurlimann, and B. Grun. 2012. "Water Conservation Behaviour in Australia." Journal of Environmental Management 1 (5): 44-52. https://doi.org/10.1016/j.jenvman.2012.03.042.

Donnenfeld, Z., C. Crookes, and S. Hedden. 2018. "A Delicate Balance: Water Scarcity in South Africa.” Accessed August 16, 2020. https://issafrica.org/research/southern-africareport/a-delicate-balance-water-scarcity-in-south-africa.

Egea, J. M., and N. G. D. Frutos. 2013. “Toward Consumption Reduction: An Environmentally Motivated Perspective." Psychology and Marketing 30 (8): 660-675. https://doi.org/10.1002/mar.20636.

Gabarda-Mallorquí, A., R. Fraguel and A. Ribas. 2018. "Exploring Environmental Awareness and Behavior among Guests at Hotels that Apply Water-saving Measures." Sustainability 10 (1-15):1305. https://doi.org/10.3390/su10051305.

Gabarda-Mallorquí, A., X. Garcia, R. Fraguell, and A. Ribas. 2020. “Are Hotel Stay Characteristics Influencing Guests' Environmental Behaviour? Predicting Water Conservation Habits." Current Issues in Tourism. https://doi.org/10.1080/13683500.2020.1829565.

Gössling, S. 2015. "New Performance Indicators for Water Management in Tourism.” Tourism Management, no. 46: 233-244. https://doi.org/10.1016/j.tourman.2014.06.018.

Gössling, S., P. Peeters, C. Hall, J. P. Ceron, H. Jean-Paul., G. Dubois, L. V. la Vergne Lehmann, and D. Scott. 2012. "Tourism and water use: Supply, Demand, and Security. An International Review." Tourism Management 33 (1):1-15. DOI: 10.1016/j.tourman.2011.03.015.

Grazzini, L., P. Rodrigo, G. Aiello, and G. Viglia. 2018. "Loss Or Gain? The Role Of Message Framing In Hotel Guests' Recycling Behaviour." Journal of Sustainable Tourism 26 (11): 1944-1966. https://doi.org/10.1080/09669582.2018.1526294.

Hair, J., J. Risher, M. Sarsstedt, and C. Ringle. 2019. "When to Use and how to Report the Results of PLS-SEM.” European Business Review, no. 31: 2-24. https://doi.org/10.1108/EBR-11-2018-0203. 


\section{Fatoki}

Han, H. 2015. “Travellers' Pro-environmental Behaviour in a Green Lodging Context: Converging Value-Belief-Norm Theory and the Theory of Planned Behaviour." Tourism Management, no. 47: 164-177. https://doi.org/10.1016/j.tourman.2014.09.014.

Han, H., and S. S. Hyun. 2018. "What Influences Water Conservation and Towel Reuse Practices of Hotel Guests." Tourism Management, no. 64: 87-97. https://doi.org/10.1016/j.tourman.2017.08.005.

Han, H., and H. J. Yoon. 2015. “Hotel Customers' Environmentally Responsible Behavioral Intention: Impact of Key Constructs on Decision in Green Consumerism.” International Journal of Hospitality Management, no. 45: 22-33. https://doi.org/10.1016/j.ijhm.2014.11.004.

Han, H., L. Hsu, and C. Sheu. 2010. "Application of the Theory of Planned Behaviour to Green Hotel Choice: Testing the Effect of Environmentally Friendly Activities." Tourism Management 31 (3): 325-334. https://doi.org/10.1016/j.tourman.2009.03.013.

Han, H., J. Lee, H. Trang, and W. Kim. 2018. "Water Conservation and Waste Reduction Management for Increasing Guest Loyalty and Green Hotel Practices." International Journal of Hospitality Management, no. 75: 58-66. https://doi.org/10.1016/j.ijhm.2018.03.012.

Kumari, M., and D. Singh. 2016. "Water Conservation: Strategies and Solutions." International Journal of Advanced Research and Review 1 (4): 75-79.

Lam, S. 2006. "Predicting Intention to Save Water: Theory of Planned Behavior, Response Efficacy, Vulnerability, and Perceived Efficiency of Alternative Solutions." Journal of Applied Social Psychology, no. 36: 2803-2282. https://doi.org/10.1111/j.00219029.2006.00129.x.

Li, G., W. Li, Z. Jin, and Z. Wang. 2019. "Influence of Environmental Concern and Knowledge on Households' Willingness to Purchase Energy-Efficient Appliances: A Case Study in Shanxi, China." Sustainability 11 (4): 1073. https://doi.org/10.3390/su11041073.

Maichum, K., S. Parichatnon, and K. Peng. 2016. "Application of the Extended Theory of Planned Behaviour Model to Investigate Purchase Intention of Green Products among Thai Consumers." Sustainability 8 (10): 1-20,1077. https://doi.org/10.3390/su8101077.

Mancosu, N., R. L. Snyder, D. Kyriakakis, Spano. 2015. "Water Scarcity and Future Challenges for Food Production.” Water 7 (3): 975-992. https://doi.org/10.3390/w7030975.

Nguyen, T., T. Nguyen, Z. Yang, and C. Thanh. 2019. "Theory of Planned Behavior Approach to Understand the Influence of Green Perceived Risk on Consumers' Green Product Purchase Intentions in an Emerging Country." International Review of Management and Marketing 9 (3): 138-147. https://doi.org/10.32479/irmm.7877. 


\section{Fatoki}

Nitzl, C., J. Roldan, G. Cepeda-Carrion. 2016. "Mediation Analysis in Partial Least Squares Path Modeling: Helping Researchers Discuss More Sophisticated Models" Industrial Management and Data Systems 116 (9): 1849-1864. https://doi.org/10.1108/IMDS-072015-0302.

Peren, K., and L. Yang. 2015. "Psychosocial and Behavioural Factors Associated with Intention to Save Water Around the Home: A Greek Case Study." Procedia Engineering, no. 119: 1447-1454. https://doi.org/10.1016/j.proeng.2015.08.1005.

Qi, X., and A. Ploeger. 2019. "Explaining Consumers' Intentions towards Purchasing Green Food in Qingdao, China: The Amendment and Extension of the Theory of Planned Behaviour." Appetite, no. 133: 414-422. https://doi.org/10.1016/j.appet.2018.12.004.

Rogerson, C. M., and J. M. Rogerson. 2020. "Covid-19 Tourism Impacts in South Africa: Government and Industry Responses.” GeoJournal of Tourism and Geosites 31 (3): 10831091. https://doi.org/10.30892/gtg.31321-544.

Saez-Fernandez, F., I. Jiménez-Hernández, and M. Ostos-Rey. 2020. "Seasonality and Efficiency of the Hotel Industry in the Balearic Islands: Implications for Economic and Environmental Sustainability." Sustainability 12 (3506):1-17. https://doi.org/10.3390/su12093506.

Sarabia-Sánchez, F. J., C. Rodríguez-Sánchez, A. Hyder. 2014. "The Role of Personal Involvement, Credibility and Efficacy of Conduct in Reported Water Conservation Behaviour." Journal of Environmental Psychology, no. 38: 206-216. https://doi.org/10.1016/j.jenvp.2014.02.003.

Schwartz, S. H., and J. A. Howard. 1981. "A Normative Decision-making Model of Altruism." In Altruism and Helping Behaviour, 89-211, edited by J. P. Rushton, and R. M. Sorrentino., Hillsdale, NJ: Lawerence Erlbaum.

Stern, P. C. 2000. "Toward a Coherent Theory of Environmentally Significant Behaviour." Journal of Social Issues 56 (3): 407-425. https://doi.org/10.1111/0022-4537.00175.

Sun, J., and V. L. Willson. 2008. "Assessing General and Specific Attitudes in Human Learning Behavior: An Activity Perspective and a Multilevel Modelling Approach." Educational and Psychological Measurement 60 (2): 245-261. https://doi.org/10.1177/0013164407308510.

Sweeney, J., G. Soutar, and T. Mazzarol. 2014. "Factors Enhancing Word-of-mouth Influence: Positive and Negative Service-related Messages." European Journal of Marketing 48 (1/2): 336-359. https://doi.org/10.1108/EJM-06-2012-0336.

United Nations Framework Convention on Climate Change. 2015. "Paris Climate Change Conference.” Accessed January 15, 2020. https://unfccc.int/process-andmeetings/conferences/past-conferences/paris-climate-change-conference-november2015/paris-climate-change-conference-november-2015. 


\section{Fatoki}

Untaru, E., A. Ispas, A. N. Candrea, and M. R. Luca. 2016. "Predictors of Individuals' Intention to conserve Water in a Lodging Context: The Application of an Extended Theory of Reasoned Action.” International Journal of Hospitality Management, no. 59: 50-59. https://doi.org/10.1016/j.ijhm.2016.09.001.

Wade, M., C. McKenzie, K. Peramaul, and M. Ferreira. 2014. “AquaSmart Hotels User Guide.” Accessed January, 15, 2020. http://www.wrc.org.za/wpcontent/uploads/mdocs/TT\%20606\%20web.pdf.

Wang, S., J. Fan, D. Zhao, and Y. Fu. 2016. 'Predicting Consumers' Intention to Adopt Hybrid Electric Vehicles: Using an Extended Version of the Theory of Planned Behaviour Model." Transportation, no. 43: 123-143. https://doi.org/10.1007/s11116-014-9567-9.

Warner, L. A., and J. M. Diaz. 2020. "Amplifying the Theory of Planned Behavior with Connectedness to Water to Inform Impactful Water Conservation Program Planning and Evaluation." The Journal of Agricultural Education and Extension. https://doi.org/10.1080/1389224X.2020.1844771.

World Travel and Tourism Council. 2019. "Travel and Tourism Economic Impact 2018 South Africa." Accessed November 20, 2020.

https://www.bbrief.co.za/content/uploads/2019/11/WTTC's-economic-report.pdf.

World Travel and Tourism Council. 2020. "Economic Impact Reports.” Accessed February 10, 2021. https://wttc.org/Research/Economic-Impact.

Zhang, L., Y. Fan, W. Zhang, and S. Zhang. 2019. "Extending the Theory of Planned Behaviour to Explain the Effects of Cognitive Factors across Different Kinds of Green Products.” Sustainability, no. 11: 1-17, 4222. https://doi.org/10.3390/su11154222. 


\begin{tabular}{|c|c|c|c|}
\hline \multicolumn{4}{|c|}{ Appendix One: Questionnaire } \\
\hline Construct & Items & $\begin{array}{l}\text { Response } \\
\text { category }\end{array}$ & Source \\
\hline $\begin{array}{l}\text { Attitude towards water } \\
\text { conservation }\end{array}$ & $\begin{array}{l}\text { ATT1. For me, conserving water } \\
\text { when staying as a guest lodging } \\
\text { establishment is positive } \\
\text { ATT2. For me, conserving water } \\
\text { when staying as a guest lodging } \\
\text { establishment is good } \\
\text { ATT3. For me, conserving water } \\
\text { when staying as a guest lodging } \\
\text { establishment is wise } \\
\text { ATT4: For me, conserving water } \\
\text { when staying as a guest lodging } \\
\text { establishment is desirable }\end{array}$ & $\begin{array}{l}1 \text { strongly } \\
\text { disagree, } 5 \\
\text { strongly agree }\end{array}$ & $\begin{array}{l}\text { Ajzen (1991); } \\
\text { Han et al. (2010); } \\
\text { Untaru et. al } \\
\text { (2016 }\end{array}$ \\
\hline Subjective norms (SN) & $\begin{array}{l}\text { - } \quad \text { SN1. People whose opinions I value } \\
\text { would prefer me to conserve water } \\
\text { when staying in a lodging } \\
\text { establishment } \\
\text { SN2. Most people who are important } \\
\text { to me think I should conserve water } \\
\text { when staying in a lodging } \\
\text { establishment } \\
\text { SN3. Most people who are important } \\
\text { to me would want me to conserve } \\
\text { water when staying in a lodging } \\
\text { establishment }\end{array}$ & $\begin{array}{l}1 \text { strongly } \\
\text { disagree, } 5 \\
\text { strongly agree }\end{array}$ & $\begin{array}{l}\text { Ajzen (1991); } \\
\text { Han et al. (2010); } \\
\text { Untaru et. al } \\
(2016)\end{array}$ \\
\hline $\begin{array}{l}\text { Perceived behavioural } \\
\text { control (PBC) }\end{array}$ & $\begin{array}{l}\text { PBC1. Whether or not I conserve } \\
\text { water when staying in a lodging } \\
\text { establishment, is completely up to } \\
\text { me } \\
\text { PBC2. I am confident that if I want, I } \\
\text { can conserve water when staying in a } \\
\text { lodging establishment } \\
\text { PBC3. I have resources, time, and } \\
\text { opportunities and knowledge to } \\
\text { conserve water when staying in a } \\
\text { lodging establishment }\end{array}$ & $\begin{array}{l}1 \text { strongly } \\
\text { disagree, } 5 \\
\text { strongly agree }\end{array}$ & $\begin{array}{l}\text { Han et al. (2010); } \\
\text { Budovska et al. } \\
\text { (2019) }\end{array}$ \\
\hline $\begin{array}{l}\text { Intention to engage in water } \\
\text { conservation when staying } \\
\text { in a lodging establishment. }\end{array}$ & $\begin{array}{l}\text { - } \\
\text { INT1.I am willing to conserve water } \\
\text { when staying in a lodging } \\
\text { establishment } \\
\text { INT2. I plan to conserve water when } \\
\text { staying in a lodging establishment } \\
\text { INT3. I will make an effort to } \\
\text { conserve water when staying in a } \\
\text { lodging establishment }\end{array}$ & $\begin{array}{l}1 \text { strongly } \\
\text { disagree, } 5 \\
\text { strongly agree }\end{array}$ & $\begin{array}{l}\text { Ajzen (1991); } \\
\text { Han et al. (2010); } \\
\text { Untaru et. al } \\
(2016)\end{array}$ \\
\hline
\end{tabular}


Fatoki

\begin{tabular}{|c|c|c|c|}
\hline \multicolumn{4}{|c|}{ Appendix One: Questionnaire } \\
\hline Construct & Items & $\begin{array}{l}\text { Response } \\
\text { category }\end{array}$ & Source \\
\hline Environmental concern & $\begin{array}{l}\text { - } \quad \text { ECI am extremely worried about the } \\
\text { state of the world's environment and } \\
\text { what it means for the future } \\
\text { EC2Mankind is severely abusing the } \\
\text { environment } \\
\text { EC3When mankind interferes with } \\
\text { nature, it often produces disastrous } \\
\text { consequences } \\
\text { - EC4The balance of nature is delicate } \\
\text { and easily upset } \\
\text { EC5Human must live in harmony } \\
\text { with nature in order to survive } \\
\text { EC6I think that environmental } \\
\text { problems are important } \\
\text { EC7I think that we should care about } \\
\text { environmental problems }\end{array}$ & $\begin{array}{l}1 \text { strongly } \\
\text { disagree, } 5 \\
\text { strongly agree }\end{array}$ & $\begin{array}{l}\text { Chen and Tung } \\
\text { (2014); Yadav and } \\
\text { Pathak (2015) }\end{array}$ \\
\hline $\begin{array}{l}\text { Water conservation } \\
\text { activities in everyday life } \\
\text { (WCA }\end{array}$ & $\begin{array}{l}\text { WCA1. At home, I turn off the } \\
\text { shower water when I am soaping } \\
\text { WCA2. At home, I turn off the tap } \\
\text { water when I am soaping } \\
\text { WCA3. At home, I turn off the tap } \\
\text { water when I am brushing my teeth }\end{array}$ & $\begin{array}{l}1 \text { strongly } \\
\text { disagree, } 5 \\
\text { strongly agree }\end{array}$ & $\begin{array}{l}\text { Untaru et. al } \\
\text { (2016); Han and } \\
\text { Hyun (2018) }\end{array}$ \\
\hline
\end{tabular}

